\title{
Erythrina, a Potential Source of Chemicals from the Neotropics
}

\author{
R. Marcos Soto-Hernández, Rosario García-Mateos, \\ Rubén San Miguel-Chávez, Geoffrey Kite, \\ Mariano Martínez-Vázquez and Ana C. Ramos-Valdivia \\ ${ }^{1}$ Colegio de Postgraduados, Campus Montecillo Mexico, Universidad \\ Autónoma Chapingo, Preparatoria Agrícola, Mexico, \\ ${ }^{2}$ Royal Botanic Gardens, Kew Richmond, \\ ${ }^{3}$ Universidad Nacional Autónoma de México, Instituto de Química Mexico, \\ ${ }^{4}$ Centro de Investigación y Estudios Avanzados del Instituto Politécnico Nacional, \\ Unidad Zacatenco, \\ 1,3,4 México \\ ${ }^{2} U K$
}

\section{Introduction}

The history of Erythrina research begins at the end of the nineteen century. During the last two decades of that time extracts from species of Erythrina have been found to exhibit curare-like neuro muscular blocking activities which are caused by alkaloids occurring there in (Rey, 1883; Altamirano, 1888; Greshoff, 1890; Folkers \& Unna, 1938).

It was Altamirano (1888), who obtained a silky shining, crystalline compound as well as Greshoff (1890) who already isolated several basic unspecified compounds. Because of their remarkable biological activity he suggested a systematic phytochemical examination of the genus Erythrina. But it still has taken at most half a century before this has been realized for the first time by Folkers. He has shown that more than fifty Erythrina species e.g. Erythrina americana (Fig. 1) are containing the typical alkaloids exhibiting the same curare-like activity reported before (Folkers \& Unna, 1939; Folkers \& Major, 1937). Moreover, his group succeeded in isolation the first erythrinane alkaloid named erythroidine (14, Fig. 3) (Folkers \& Koniouszy, 1939). Soon after numerous alkaloids have been isolated, e.g. erythramine (8) (Folkers \& Koniouszy, 1940a), erythraline (3) (Folkers \& Koniouszy, 1940b), erythratine (9) (Folkers \& Koniouszy, 1940c), erysodine (6), erysopine (4) and erysovine (5) (Carmag, et al. 1951).

Another decade later the fundamentals investigations of Prelog (Kenner, et al., 1951; Tsuda \& Sano, 1996) and Boekelheide (Boekelheide, et al. 1953) have finally led to the correct structural framework of the erythrinane alkaloids (Parent compounds 1, Fig. 2)

Due to the increasing attraction and rapid extension in this field the Erythrina alkaloids have been regularly reviewed concerning occurrence, structure, analytical, spectral properties, 


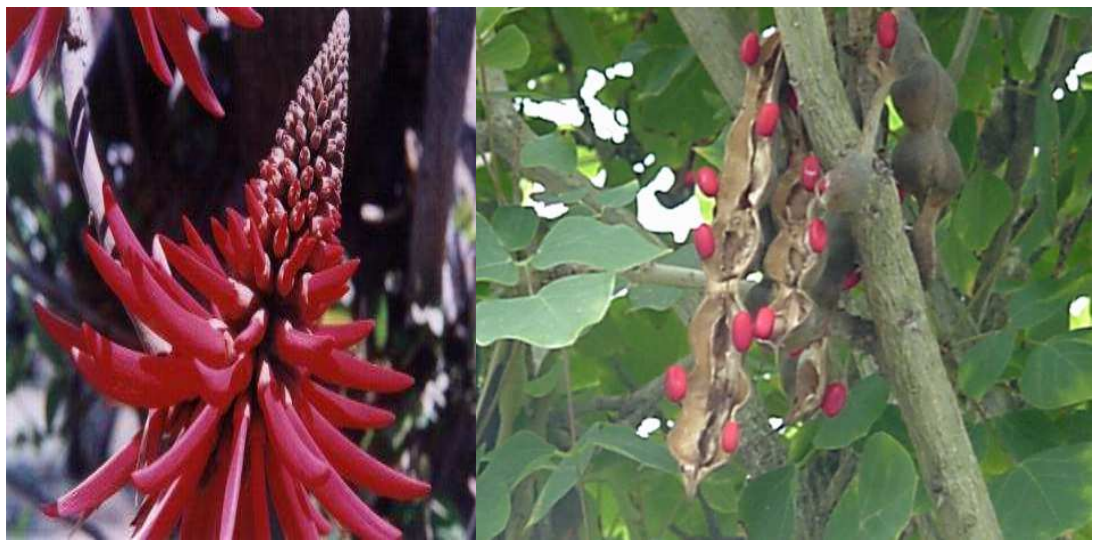

Fig. 1. Erythrina americana Mill (Colorin)

biosynthesis, total synthesis and biological activities covering the literature up to date. Besides compounds as flavonoids, isoflavonoids, lectins, saponins have received special attention mainly by their biological activity or toxicity.

This review has the aim to show the evolution in the knowledge of these ubiquitous compounds that remark the Erythrina genus and emphasize their importance and interest in different areas.

\section{Structural classification of Erythrina alkaloids}

The alkaloids of Erythrina type are characterized by their unique skeleton of a tetracyclic spiroamine. They are classified in two main groups: alkaloids possesses a skeleton of a 6,5,6,6 indoloisoquinoline called erythrinanes and those with a skeleton of 6,5,7-6 indolobenzazepine called schelhammerans or homoerythrinane alkaloids (Fig. 2).

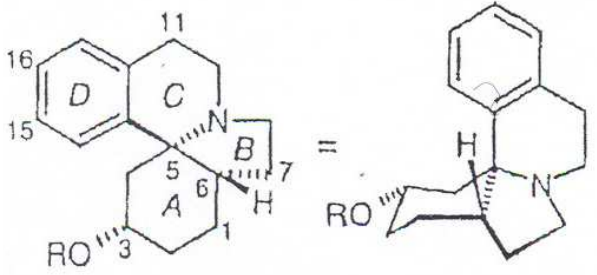

(3R,5S,6S/3S,5R,6R)-Erythrinane (1)
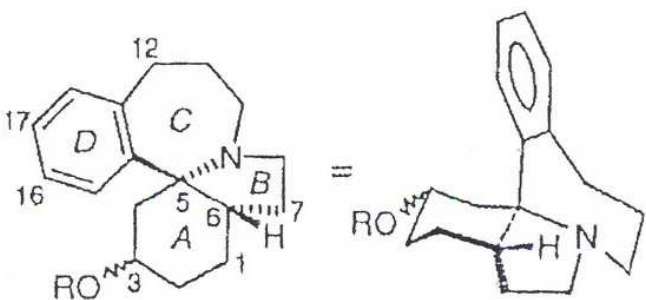

(5S,6S / 5R,6R)-Schelhammerane (2) (homoerytrinane alkaloids)

Depending of the nature of $\mathrm{D}$ ring both groups can be subdivide in aromatic and non aromatic. In this last group that include in the D ring oxa compounds, are those called lactonic alkaloids. Besides, in both series have been isolated alkaloids with a pyridinium group instead of a phenyl group, for example the erymelanthine (11) and the holidine (12). 
Dienoid Type:

\section{Aromatics}

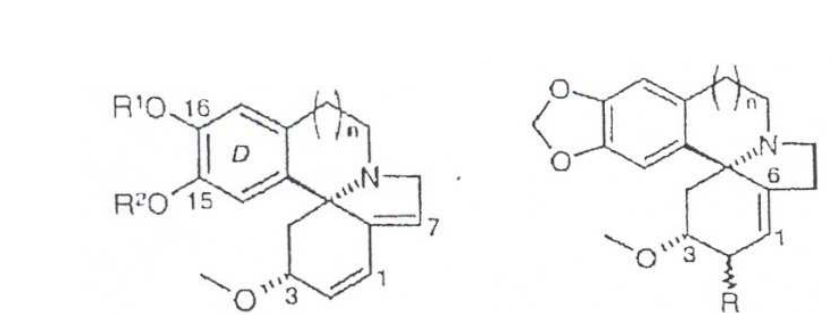

Alkenoid Type:

$\mathrm{R}^{1}-\mathrm{R}^{2}=\mathrm{CH}_{2} ; \mathrm{n}=1$ : Erythraline (3)

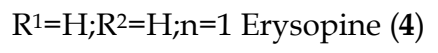

$\mathrm{R}=\mathrm{H} ; \mathrm{n}=1$ : Erythramine (8)

$\mathrm{R}^{1}=\mathrm{CH}_{3} ; \mathrm{R}^{2}=\mathrm{H} ; \mathrm{n}=1$ Erysovine (5)

$\mathrm{R}=\beta-\mathrm{OH} ; \mathrm{n}=1$ Erythratine (9)

$\mathrm{R} 1=\mathrm{H} ; \mathrm{R}^{2}=\mathrm{CH}_{3} ; \mathrm{n}=1$ Erysodine (6)

$\mathrm{R}=\mathrm{H} ; \mathrm{n}=2:$ Schelhammericine $\mathbf{( 1 0 )}$

$\mathrm{R}^{1}-\mathrm{R}^{2}=\mathrm{CH}_{2} ; \mathrm{n}=2$ : Schelhammeridine (7)

\section{Heteroaromatics}<smiles>COC(=O)c1cc2c(cn1)CCN1CCCC21</smiles><smiles>COC(=O)c1cc2c(cn1)CCCN1CCC21[C@H]1C=CC[C@@H](OC)C1</smiles><smiles>COC(=O)c1cc2c(o1)CCCN1CCCC21[C@H]1CC[C@@H](OC)CC1</smiles>

Erymelanthine (11) Holidine (12) Selaginoidine (13)

\section{Non-aromatics}

(lactonic)

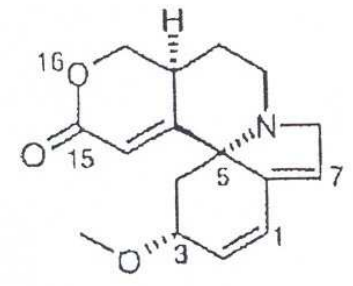

Erythroidine (14)

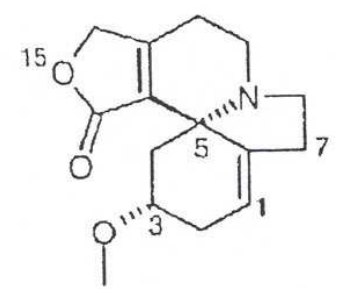

Cocculolidine (15)

Fig. 2. General classification of Erythrina alkaloids: Dienoid and alkenoid type alkaloids and D ring modifications. 
Besides, the specific position and number of double bonds in the A and B rings have taken to another alkaloid sub division: dienoid and alkenoid in both series. The first ones are characterized by a conjugated diene in the 1,2,6 and 7 carbons whereas the last ones possesses only one a double bond in the position $1,6(8,9)$.

As aromatic erythrinane alkaloids and homoerythrinanes as well show a substitution characteristics pattern, e.g. present oxygenated substituents in the 3,15 and 16 carbons mainly and besides there is a group of alkaloids deoxygenated in C-16,the saturated compounds in both series of alkaloids have cis configuration in the fussion $A / B$ independently that had obtained by transformation of natural alkaloids or by synthesis (Mondon, et al., 1970; Reiman \& Ettmayr, 2004).

Generally these alkaloids are dextrorotatory and their absolute configuration in the carbon 5 is (S) to respect to basic skeleton (Amer, et al., 1991), although is observed some exceptions as the wilsonine (49) has configuration (R) in the carbon 5.

The carbon 3 of the erythrinanes always have the configuration R.

\section{Biosynthesis of the erythrinane alkaloids}

A series of experiment in vivo and in vitro done by Barton and coworkers (Barton \& Cohen, 1957; Barton et al.,1970) demonstrated that a derivative of an isoquinoline, the (5)norprotosinomenine (Bencyl-tetrahydroisoquinoline (34) is the main precursor to which is cyclized through a phenolic coupling $p$ - $p$ to a derivative of a neoproaphorfine (35).

In this is effected a rearrangement to form a dibenzazonine (36). Its hydrogenation product (37) is oxydized to the corresponding diphenoquinone 38. To the end occurs an intramolecular addition type Michael to form the erysodienone (39) which already has the skeleton of an erythrinane (Barton \& Cohen, 1957; Barton, et al., 1970; Barton, et al., 1974). Both precursors 34 and 37 are compounds of natural origin (Scheme 1). Later on this route was reinvestigated by Maier \& coworkers (Maier \& Zenk 1997; Maier, et al., 1999) because was observed only occurred a small rate of relative incorporation of non protosinomenine (34) in the erythraline (3) $(0.1-0.25 \%)$ someone not usual to the group of alkaloids with isoquinoline skeleton derivated of (S) reticuline (40: $\mathrm{NCH}_{3}$ instead of $\left.\mathrm{NH}\right)$ e.g. aporphines, protoberberine, bisbencylisoquinolines, morphinones, pavines and benzophenanthridines.<smiles>COc1ccc(C=CC2NCCc3cc(O)c(OC)cc32)cc1O</smiles>

S-Norprotosinomenine (34)

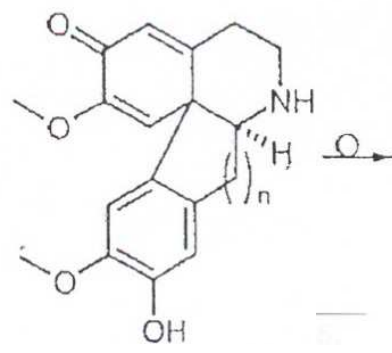

Neoproaporphine (35)

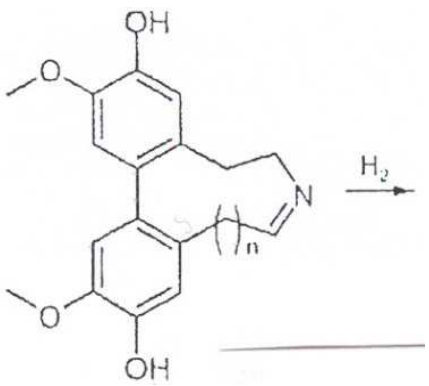

(36) 


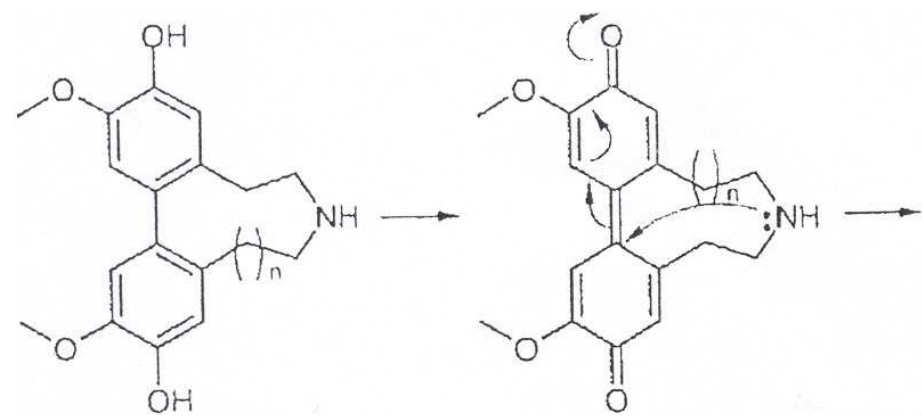

Dibenzazonine (37)

Dibenzazonine dione (38)<smiles>C=CC(=O)C(=CC12CCCN1CCc1cc(O)c(OC)cc12)OC</smiles>

Erysodienone (39)

Scheme 1.

It was observed by this way that the (S)- non reticuline (40) is the biosynthetic precursor more important to the erythrinane alkaloids and that the rate of incorporation surpassed by for that of (S) norprotosinomenine(34) previously found (7.9\%) against $0.25 \%$ in the case of erythraline and this last one did not transform in another alkaloids. This can suggest a new route and mechanism to the biosynthesis of the alkaloids (Scheme 2)

In this model, the $p-p$ coupling of the (S) nor reticuline should take to the derivative of the morphinanedienone, the norisosalutanidine (41) and not to the neoproaporphine derivative (35).

The last one, after formation the function benzo [1,3]dioxol forms the noramurine (42), which can rearrange via the ion neoespirinic (43) to the unsymmetrical dibenzazonine oxidation of the free phenolic residue proceeds through a SET mechanism to form diallylic cation (45), the last one is supposed that reacts with the nitrogen atom to get $\Delta^{3}$ erythratinone (46).

The subsequent steps leading to erythraline (3) are similar to those already established (Maier, et al., 1999 ).

\section{Syntheses of Erythrina alkaloids and compounds type Erythrine}

Since some time ago had interest in the total synthesis of the Erythrina alkaloids because their unique structure and biological activity. In this way has been developed to date numerous synthetic approaches to the tetracyclic skeleton. Considering that three of the rings $A, B$ and $C$ can be joint in a final step,have been developed two synthetic strategies to this type of compounds: the formation of one of the mentioned rings (route $A, B$, or $C$ ) or the simultaneous or sequential formation of more than one cycle for example $A / B, A / C, B / C$ or A/B/C in one step (called routes A/B, B/C, etc. schemes 3,4).

Various subtypes of the synthesis result depending of the bond formed (Schemes 3,4): for example the formation of the $C$ ring can be attain through the method (a) or (b) = route $C(a)$ or C (b).

According to this can be generate two different subdivisions to the simultaneous construction of the B and C rings ( = route B/C (a) or B/C (b) (Kawasaki, 2001) 


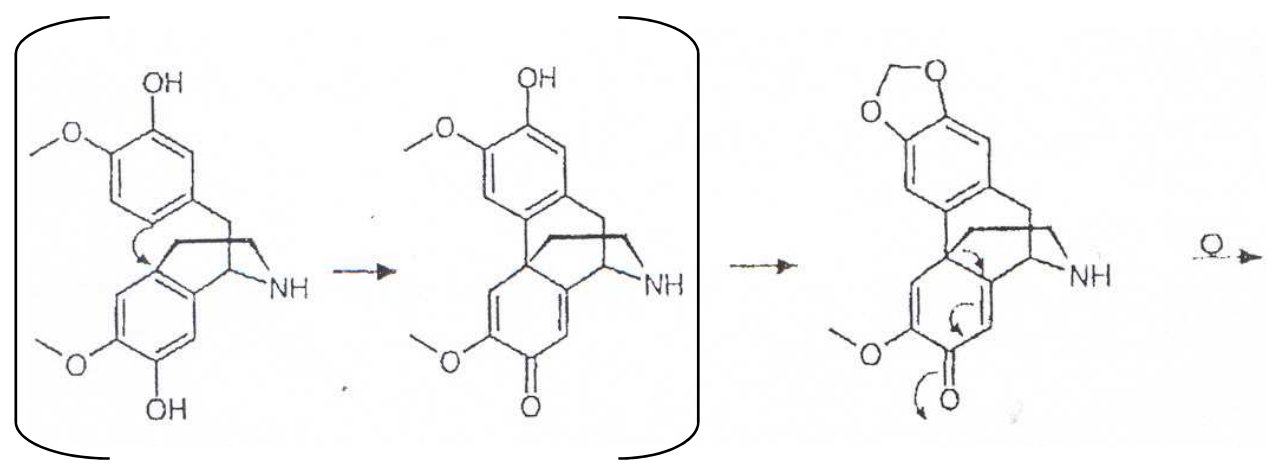

(S)-Norreticuline (40) Norisosalutaridine (41)

Noramurine (42)

(n)

Neospirinic cation (43)<smiles></smiles>

(45)<smiles></smiles><smiles>[CH]1[CH]C=C1</smiles>

$\Delta^{3}$-Erythratinone (46)

Scheme 2. Biosynthetic pathway of Erythrina alkaloids suggested by Maier, et al. (1999) 


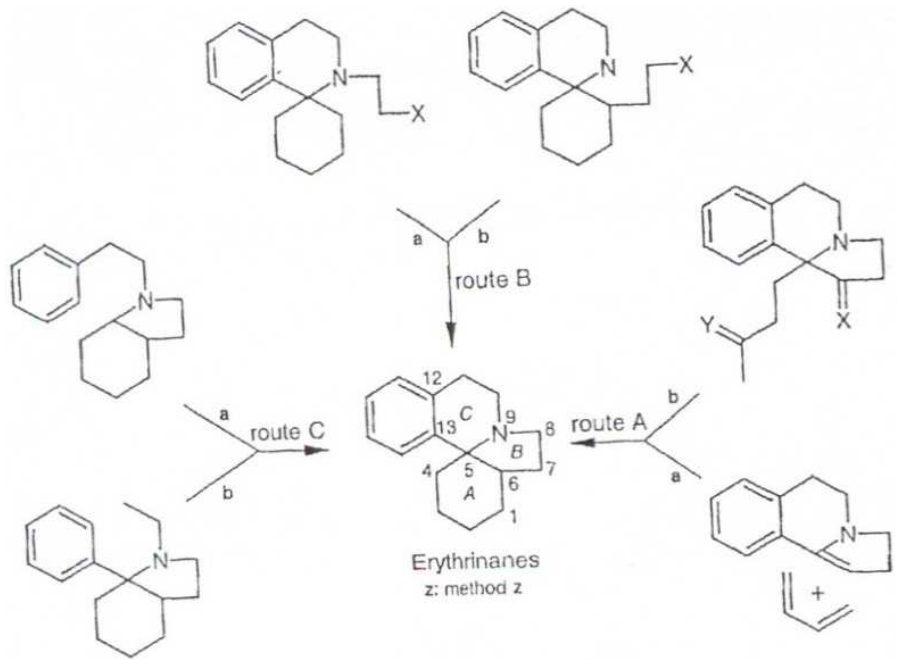

Scheme 3. Synthetic strategies to the aromatic erythrinane alkaloids. Generation of an alicyclic ring in the final step<smiles>C=CCCCC1c2ccccc2CC[N+]1(C)C</smiles>

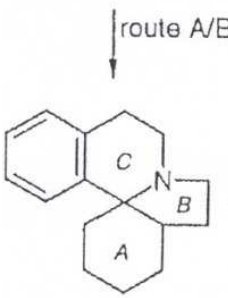

Erythrinanes

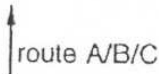<smiles>C/C=C\CN(CCc1ccccc1)C(=[W])/C=C\C</smiles><smiles>CC(C)Br</smiles><smiles>[X]CCN(CCc1ccccc1)C1CCCCC1</smiles><smiles>c1ccc(CCNCCc2ccccc2)cc1</smiles><smiles>c1ccc(CCNCCC2CCCCC2)cc1</smiles>

z: $\operatorname{method} z$

Scheme 4. Strategies to the synthesis of aromatic erythrinane alkaloids. Generation of more than one alicyclic ring for tandem sequential cyclization in the final step or in one step. 
In the case of the non aromatic Erythrine alkaloids, only has described one total synthesis so far. Thus the synthesis of the $( \pm$ ) coculolidine (15) has been completed in $0.42 \%$ total yield through 21 steps (Kawasaki, et al., 2001). Also has been described several synthetic approaches to the D ring of the oxaerythrinane skeleton (Studa \& Sano, 1996).

\section{Spectroscopic characteristics of the Erythrina alkaloids}

In the structural determination of these alkaloids have been used widely the common spectroscopic techniques e.g. UV, IR, and ${ }^{1} \mathrm{H}$ NMR ${ }^{13} \mathrm{CNMR}$, besides of mass spectrometry and $X$ ray crystallography.

The aromatic alkaloids show IR absorption to $1610 \mathrm{~cm}^{-1}$ and in the UV in the range of 285$290 \mathrm{~nm}$ (aromatic deoxygenated ring) and 235-240 $\mathrm{nm}$ (of the diene residue). The alkenoid alkaloids absorb in the UV about of $225 \mathrm{~nm}$, whereas the enone residue shows absorption to $230 \mathrm{~nm}$ and in IR between 1675-1698 $\mathrm{cm}^{-1}$. The lactonic alkaloids absorb in the IR to 1720 $\mathrm{cm}^{-1}$ (carbonyl of the lactone) whereas in the UV its absorption is about 224 and $238 \mathrm{~nm}$.

The ${ }^{1} \mathrm{H}$ - NMR easily distinguish to the dienoid alkaloids by the presence of a ABX system comes from the three olefinic protons pattern does not presented the alkenoid alkaloids or the lactonic alkaloids.

The ${ }^{13} \mathrm{C}$ spectra of various erythrinane alkaloids has been assigned by comparison with series of related compounds or well through the case of model compounds, the spirocenter at C-5 usually absorb at $\delta$ 63-68. The tertiary aromatic carbons of those of C-14 present a chemical shift to high field $(\delta 108-112)$ whereas that at C-17 is observed about $\delta 111-117$.

The mass spectrometry had an important role in the structural identification of these alkaloids particularly when is combined with gas chromatography or liquid chromatography. An analysis of a mass spectrum to those alkaloids shows in the case of those aromatic or lactonic that occurs a main fragmentation of the methyl or methoxy group in C-3 (Fig. 3) In the series of the alkenoid alkaloids also is observed this type of fragmentation, but is observed another peak at $\mathrm{M}^{+}-58$ which corresponds to a retro Diels-Alder fragmentation. Loss of C-3, C-4 and methoxy group at C-3 also is observed in this series (Fig. 4).
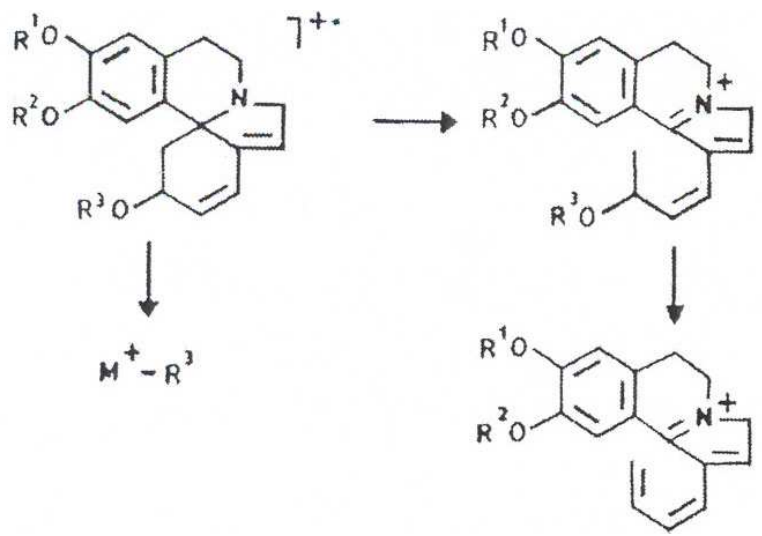

Fig. 3. Fragmentation of dienoid alkaloids 


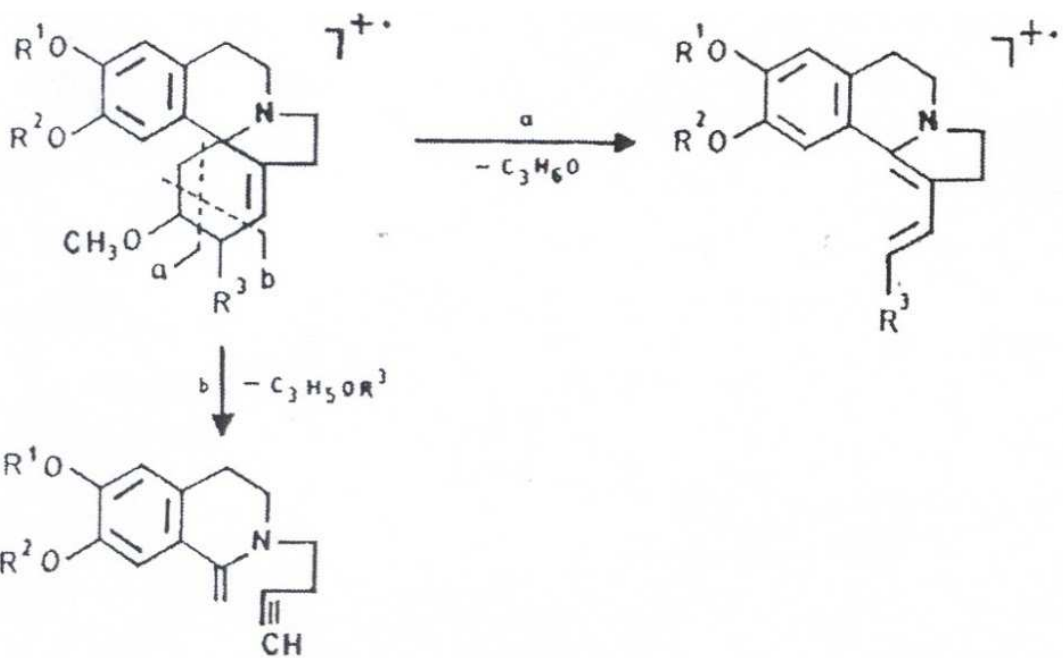

Fig. 4. Fragmentation of the alkenoid alkaloids

Following MS/MS analysis in an ion trap analyser, Erythrina alkaloids methoxylated at C3 show the neutral loss of methanol from the protonated molecule but few other abundant fragments. Thus MS3 analysis of the $\left[(\mathrm{M}+\mathrm{H})-\mathrm{CH}_{3} \mathrm{OH}\right]+$ is necessary to obtain a greater array of fragments, which is necessary to confirm identities against standards of for library spectra (Fig. 5). Several product ions generated from the $\left[(\mathrm{M}+\mathrm{H})-\mathrm{CH}_{3} \mathrm{OH}\right]^{+}$fragment appear to be produced by radical losses of methyl or hydroxyl groups. Glycosylated forms of Erythrina alkaloids are also evident in some species when crude extracts are analysed by LC-MS, and they may be the most abundant types present. Fragmentation of the glycosides proceeds via neutral loss of the glycosyl unit to yield a protonated aglycone ion that fragments in the same manner at the free protonated alkaloid. Undoubtedly, systematic surveys of native Erythrinane alkaloids in Erythrina species by LC-MS will reveal a greater variety of glycosilated or other conjugated forms than have presently been isolated.

In this sense all parts of Erythrina plants have been screened to describe new compounds, for instance Wanjala \& Majinda (2000) described the structures of two novel alkaloids from $E$. latissima seeds; from the wood of E. poeppigiana Tanaka et al, (2001) isolated a new erythrina alkaloid, 8-oxo-a-erythroidine. From the flowers of E. speciosa two alkaloids were isolated, erysotrine and erythartine and the leaves furnished one alkaloid, nororientaline, Faria, et al (2007.) Three new alkaloids, 10,11-dioxo-erythrartine, 10,11-dioxoepierythratidine and 10,11dioxo erythratidinone and a new pterocarpan 1-methoxyerythrabissin were isolated from the bark of E. subumbrans (Rukachaisirikul, et al., 2008). A new Erythrina alkaloid, 10-hydroxy-11oxo-erysotrine has been isolated from the flowers of E. herbacea (Tanaka \& Hattori, 2008). From the bark of E. crista-galli two new alkaloids, cristanines A and B were isolated (Ozawa, et al., 2010) and from the seeds of E. velutina were isolated four new alkaloids, three of them were found to be novel sulfated erythrinane alkaloids (Ozawa, et al., 2011).

It is interesting to note that in the 2000 decade the literature described not only the isolation of new structures but also related them with biological activity, for instance Juma \& Majinda (2004) described the isolation of fourteen different Erythrina alkaloids from the flowers and 
pods of E. lysistemon and tested their DPPH radical scavenging properties against stable 2,2diphenyl-1-picrylhydrazyl (DPPH) radical. The antifeedant activities of the Erythrina alkaloids from the seeds, seed pods and flowers of E. latissima were investigated in laboratory dual-choice bioassays using third -instar Spodoptera littoralis (Boisduval) larvae (Wanjala, et al., 2009) and they found a dependant activity at concentrations between 100$500 \mathrm{ppm}$. The seed pods of E. latissima were studied by Wanjala \& coworkers (Wanjala, et al., 2002), they found in this tissue the known alkaloids, erysotrine and erysodine and a new alkaloid, 10,11-dioxoerysotrine, which was lethal to brine shrimp and a 2-(5'-hydroxy-3'methoxy phenyl)-6-hydroxy-5-methoxybenzofuran, which showed strong antimicrobial activity against the yeast spores, Gram-positive and Gram-negative bacteria.

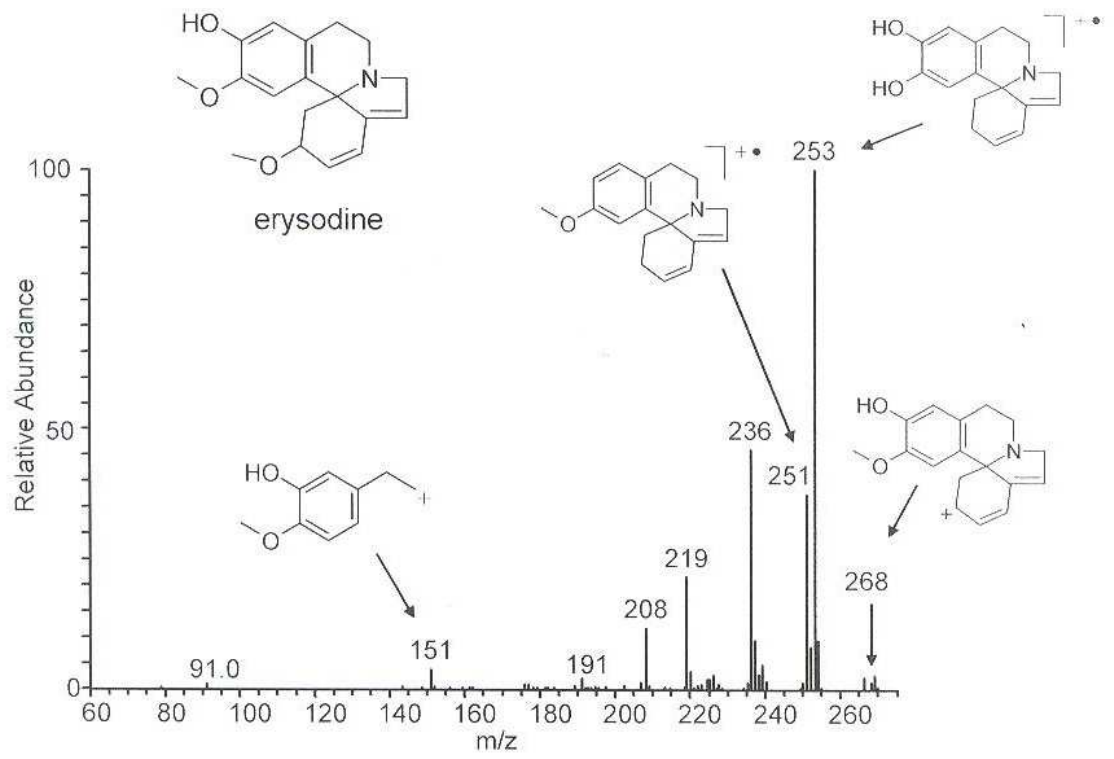

Fig. 5. MS $\left(\mathrm{m} / z 313[\mathrm{MH}]^{+} \rightarrow 268\right)$ spectrum of erysodine recorded on a Thermo-Scientific I.CQ Classic quadrupole ion trap mass spectrometer.

\section{Analysis of Erythrina alkaloids by liquid chromatography}

These alkaloids has been analyzed traditionally by gas chromatography coupled to mass spectrometry (GC-MS). Although is possible analyze some of these alkaloids directly by this technique (Mantle, 1995) the method is improved with chemical derivatization, for example with trimethyl silylation the volatility of the compounds in increased (Jackson, et al., 1982). The glycosylated compounds are hydrolyzed to release the aglycone and facilitate the analysis. By this way the technique has been valuable in the analysis of several species of Erythrina (Soto-Hernandez \& Jackson, 1994) also to compare hydrolyzed form with non hydrolyzed the levels of conjugated alkaloids can be deducted.

Besides, the high resolution of the hyphenated technique helps in the distinction of isomers, but the derivatization could complicate the analysis to form artifacts or could be incomplete and the method is consuming time.These observation made to look another technique with 
lesser inconveniences e.g. the coupling of HPLC with mass spectrometry referred as HPLCMS. As these alkaloids easily accept protons, are ionized efficiently in positive mode with ionic sources as electrospray (ESI) or chemical ionization at atmospheric pressure (APCL). This last ionization mode is obtained higher sensitivity to the aglucones. Being basic compounds is low probable that their ionization is depleted in positive mode by other compounds, allowing that is detected easily by direct injection of a crude extract of alkaloids. However when is presented isomeric forms should be separated them before their analysis by mass spectrometry.

In one first step, the analysis of these alkaloids by HPLC with UV detection has been done with a normal phase column (Soto-Hernandez \& Jackson, 1994). Later on was used the columns in reverse phase $\mathrm{C}-18$ which at the beginning had low resolution and presented adverse effects to occur interactions between the charged alkaloids and negative residue charge from the stationary phase of the column. Also these compounds have been analyzed in the ionic pair mode. To diminish the positive charge of them, this mode (Fabre, et al. 2000) took to propose a method of analysis with the combination HPLC-MS, but the use of the present C-18 columns can remove the participation of the ionic volatile reagent (Verpoorte \& Niesse, 1994).With them are managed in basic $\mathrm{pH}$ to increase the retention of the alkaloids and suppress the ionization of the $\mathrm{OH}$ groups in the stationary phase, this criteria helped in the analysis of the alkaloids of Erythrina herbacea that allowed a good separation and detection of the alkaloids, starting from a crude extract of the plant in which was used a programmed gradient of $0.1 \%$ ammonium acetate (at $\mathrm{pH} 7.4$ ) and methanol (Garin-Aguilar, et al., 2005). However, with the recent incorporation of C-18 column with phenyl group linked to ethers, designed specifically to retain polar aromatic compounds, results suitable to the analysis of these alkaloids using simply a gradient of aqueous methanol and the method is still acceptable in acidic methanol (Fig. 5) by this way the acidic mobile phase promote the protonation of the alkaloids and improve their sensitivity.

\section{Pharmacology}

The biological activity of extracts of Erythrina species is known since long time ago. Thus, the natives of South America used concentrated extracts of these species as arrow poisons as antidote against strychnine or as an hypnotic and antiepileptic (Folkers \& Unna, 1938). Also was observed that when is applied to dogs at different doses an alcoholic extract of seeds of E. americana provoked a similar activity to that of tubocurarine, this action was confirmed later on (Lozoya \& Lozoya, 1982)

The first crystalline alkaloid pharmacologically active was isolated from E. americana (Folkers \& Major, 1937) called erythroidine. Altamirano used this name but he related it as a unknown constituent of the plant. The subsequent analysis showed that this material was a mixture of isomeric alkaloids to which were called $\alpha$ - and $\beta$ - erythroidines $(47,48)$

Between 1940 and 1950 the systematic review of more than 50 species of Erythrina showed that all the isolated alkaloids produced similar effects to those of the curare alkaloids ( Pick \& Unna, 1945) used before as adjuvants in surgical anaesthesia, this stimulated the systematic investigation of the Erythrina species related to the biological properties of their extracts. 


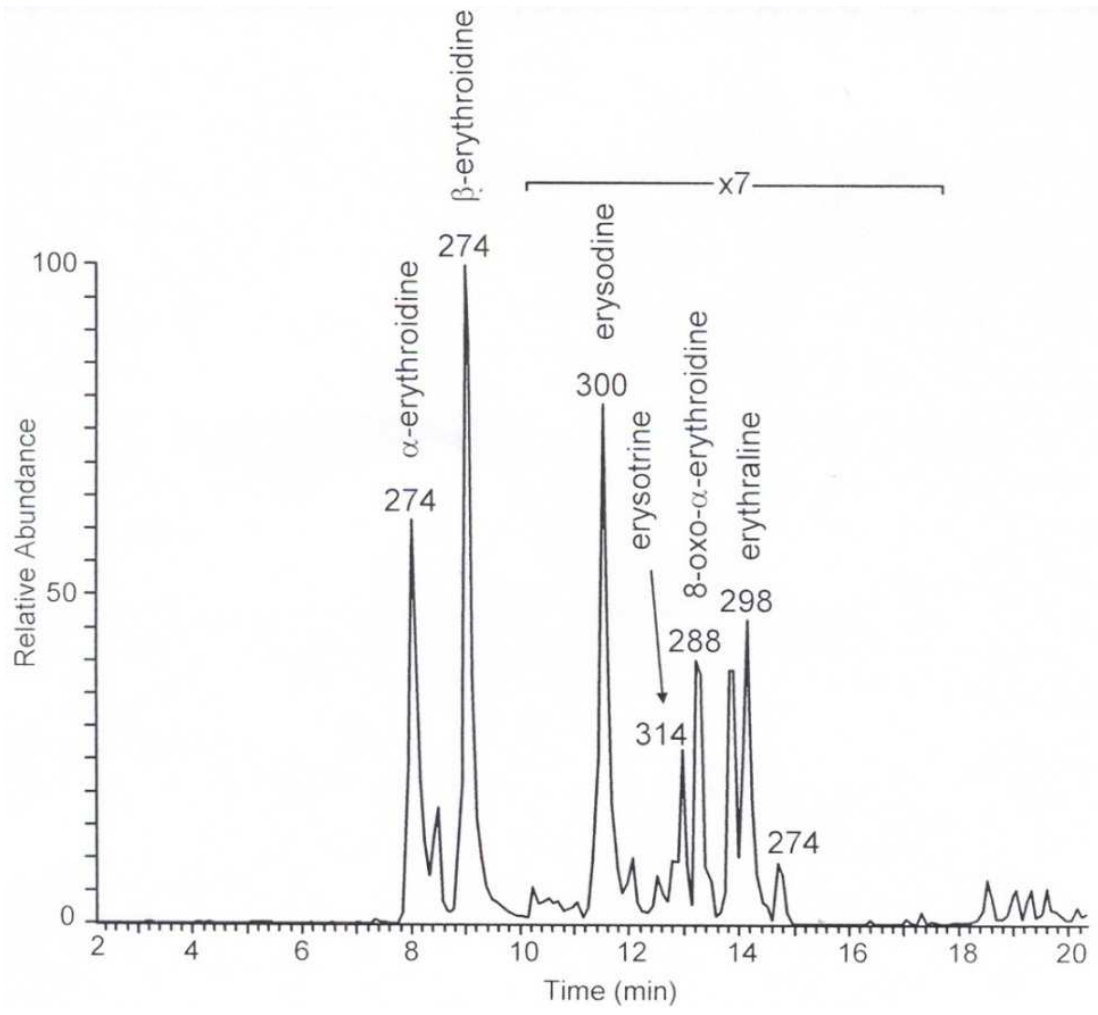

Fig. 6. Chromatogram of a LC-MS analysis of a methanol crude extract of E. americana seeds. The analysis was done in a phenomenex RP polar column of $150 \times 46 \mathrm{~mm}$, using a gradient of $0-10 \%$ methanol in the mobile phase (acidified with $1 \%$ acetic acid). Detection with APCI. The figures near to the peaks are the values of $[\mathrm{M}+\mathrm{H}]$.<smiles>CO[C@@H]1C=CC2=CCN3CCC4=C(CC(=O)OC4)[C@]23C1</smiles>

$\beta$-erythroidine (47)<smiles>CO[C@H]1CC=C2CN3CCC4=C(CC(=O)OC4)[C@@]23C1</smiles>

Dihydro- $\beta$-erythroidine (48)<smiles>COc1cc2c(cc1OC)[C@@]1(C=C[C@@H](OC)CC1)[C@@H]1CCCN2C1</smiles>

Wilsonine (49)

Fig. 7. Structure of various Erythrina alkaloids with special pharmacological properties.

Several species have been used in the indigenous medicine as eyewashes or wounds, for pain relief of arthritis or as calm and relaxants agents (Garin-Aguilar, et al., 2000). Interesting also has been described the hypoglycemic activity of $E$. variegata leaf in streptozotocininduced diabetic rats (Kumar, et al., 2011) and the authors conclude that leaf of this plant has promising hypoglycemic action in STZ-induced diabetic rats substantiating in this way 
the ethnomedical use. The study of the antidiarrhoeal effects of ethanolic leaf extract of $E$. indica L. in experimental animals done by Sonia and coworkers (Sonia, et al., 2011) showed that this extract elicit potential antidiarrhoeal effects and thus substantiated its traditional claim as an antidiarrohoeal agent, also their findings suggest that the main constituents of the extracts were alkaloids

Also they have been related with antiasthmatic, diuretic or hypnotics properties. The alkaloidal extracts of $E$. variegata besides of its smooth properties as muscular relaxant has found depressed activity of the CNS and anticonvulsant, also increase the hypnosis provoked by pentobarbital and inhibit the acetyl choline induced spasm. Extracts of $E$. velutina and E.suberosa have spasmolytic and antineoplastic activity (Ghosal, et al., 1972; Craig, 1955). In recent researches crude extracts of $E$. americana as well their pure constituents: $\beta$-erythroidine and dihydro- $\beta$-erythroidine (Fig. 7 ) diminished the aggressive behavior in rats when is used diazepam as control. These effects are attributed to an interaction between the cholinergic and GABAergic receptors. Besides was determined the $\mathrm{LD}_{50}$ of the extracts as well to the pure alkaloids. From all the pure alkaloids tested the aand $\beta$-erythroidine showed the highest activity (Garin-Aguilar, et al., 2000). It is considered that they are responsible of the hypnotic activity of the extracts of the flowers of E. americana (Tsuda \& Sano, 1996). The $\beta$-erythroidine and its more potent derivative (2,7-dihydro) (48) have been used as muscular relaxants in numerous clinical applications (Lozoya \& Lozoya, 1982). This activity is attributed to a antagonistic action of the dihydro $\beta$-erythroidine with the nicotinic receptors of acetyl choline (Tsuda \& Sano, 1996; Cheeta, et al., 2001; Schoffelmer, et al., 2002).

Subsequently the group of Iturriaga-Vasquez and coworkers (Iturriaga-Vasquez, et al., 2010) studied the molecular determinants for competitive inhibition of a4 $\beta 2$ nicotinic acetylcholine receptors provoked by the dihydro- $\beta$-erythroidine $(\mathrm{DH} \beta \mathrm{E})$. They addressed this issue by examining the effects of $\mathrm{DH} \beta \mathrm{E}$ and a range of aromatic Erythrina alkaloids on $\left[{ }^{3} \mathrm{H}\right]$ cytisine binding and receptor function in conjunction with homology models of the a $4 \beta 2 \mathrm{nAChR}$, mutagenesis and functional assays. They found that the lactone group of $\mathrm{DH} \beta \mathrm{E}$ and a hydroxyl group at position C-16 in aromatic Erythrina alkaloids were identified as major determinants of potency, which was decreased when the conserved residue Tyr 126 in loop $\mathrm{A}$ of the a4 subunit was substituted by alanine.

Erysodine (6) has found as competitive reversible antagonist of nicotine and the induced release of dopamine. It is equipotent with the dihydro- $\beta$-erythroidine (48) and can be used as tool to characterize neuronal nicotinic receptors of acetyl choline.

The anxiolytic effects of the E. velutina aqueous alcoholic crude extract and the purified alkaloids of the flowers of this plant were evaluated using the elevated T-maze test, and the light dark transition model( Flausino, et al., 2007a; Flausino, et al., 2007b). They observed a moderate activity but explain the use of the plant as calm agitation and other disorders of the nervous system. Subsequently, Carvalho, et al., (2009) showed an evidence of the mechanism of action of the leaves aqueous extract of this plant and they found that this extract provokes a $\mathrm{GABA}_{\mathrm{A}}$ receptor activation, acetylcholine release, muscarinic receptor activation, augmentation of $\mathrm{Ca}^{2+}$ entry though L-type calcium channels, and calcium release from the intracellular stores and they mention that their findings provide further support for E. velutina traditional uses. 
However the study of Silva and coworkers (Silva et al., 2011) put in attention the use of this plant because through genotoxicity and cytotoxicity experiments on the root meristem cells of Allium cepa showed that the decoction of the leaves can have genotoxic effects at some doses and they recommend caution when using this plant for the preparation of teas and other medicinal products.

The group of Atsarno \& coworkers (Atsarno, et al., 2011) evaluated the potential toxicity of the decoction of the stem bark of E. senegalensis which is used traditionally in Cameroon against liver disorders. Their results demonstrated that there is a wide margin of safety for the therapeutic use of this decoction and further corroborated the traditional use of this extract as hepatoprotective agent.

The analgesic properties of extracts and fractions from E. crista-galli leaves were tested by Fischer, et al., (2007) and they found that one of the fractions was the most active, being about 7-fold more active than the reference drugs(acetyl salicylic acid and acetaminophen)

It is important to mention that the curare alkaloids as quaternary salts and by their potent solubility in water are administered parentally. In contrast the Erythrina alkaloids are tertiary amines and they are able to develop their pharmacologic effects by oral via.

\section{Chemotaxonomy}

The alkaloids has been proposed as possible taxonomic markers is several species of angiosperms and this has helped to the resolution of some taxonomic problems, their limited distribution make that they can not be employed in the higher level of taxonomic classification only in those orders and classes where they are represented.

In this way the chemotaxonomy of alkaloids is found well documented but only to certain families of angiosperms (Hegnauer, 1963). In the case of Erythrina plants has been studied the alkaloid content in approximately half of the known species and the relationship of them is reflected in the presence of a series of alkaloids with isoquinoline skeleton.

Although the pattern of alkaloids of this genus is characteristic, their concentration varies. Hargreaves \& coworkers mentioned that in the American species the proportion of alkaloids differs widely. The results indicate that in the genus, the dienoid alkaloids erysodine, erysovine and erysopine are the most abundant and widely distributed. In the American species the alkaloids generally do not contain oxygenated functions in C-11 may be by the enzymatic lack to hydroxylate this position (Hargreaves, et al., 1974). Aguilar \& coworkers pointed out that in E. americana is typical to find lactonic alkaloids as main compounds (Aguilar, et al., 1981).

In E. folkersii has been found alkaloids of the type 1,6-diene and in E. salviflora those of alkenoid type. Ghosal \& coworkers mentioned that erysotrine is the most abundant alkaloid in bark of $E$. variegata var. orientalis but also has been identified the erysodine in a lesser amounts (Ghosal, et al., 1972), whereas Dyke \& Quessy mentioned that only is found erysodine in the bark of the same species (Dyke \& Quessy, 1981). In some species is frequent to find alkaloids to contain oxygenated functions in the C-8 and C-11 position of the erythrinane skeleton, still exist doubts respect if one species is synonym to other. As the case of E. americana which some authors mention is synonym of E. coralloides. To prove that they are different species San Miguel-Chavez \& coworkers found that the plantlets of one 
month age of E. americana synthetize erysosalvine, erythraline, $\mathrm{N}$-oxide, erythratine and 8oxo-a-erythroidine, whereas those of $E$. coralloides presented only erythraline and erysopine. These observations together with those of the morphology of the plantlets gives the idea of both species are different (San Miguel-Chavez et al., 2006).

\section{Biotechnology in the production of Erythrinane alkaloids}

Is well known that most of the drugs using in medicine are synthetic but some of them are of natural origin. Their demand is so high that some of plants are cultivated to this aim and to get enough biomass for the extraction of the drugs.

To satisfy the demand and protect the natural resources, has been developed alternative methods as Biotechnology plant cell tissue culture or the chemical synthesis and has been observed better results comparing with the traditional methods (Bougard, et al., 2001; Murphy, 2011).

Except to cultivated plants (e.g. Papaver somniferum) most of secondary metabolites are accumulated after certain age or maturity of the plant e.g. trees or shrubs (Cinchona, Rauwolfia, Campotheca, Ochrosia, etc)

The plants obtain their maturity before accumulate the active principles in higher amounts and is difficult increase the plantation to particular species. To avoid all of these limitations is required alternative methods to get a constant material all the year. To collect the plants in their natural environment is difficult but also put in risk of extinction some of them. When the plant material is not obtained during the year in enough amount to industrial scale and the chemical synthesis is not possible particularly in the case of complex molecules, the biotechnological methods give an excellent alternative. However to get this option should be consider cost/benefit of the product and then justify its its production (Bourgard, et al., 2001; Murphy, 2011).

E. americana had a wide distribution in México but recently its natural populations have started down because to the disappearance of its habitats.

This species also have interest because by the production of alkaloids with pharmacological and antimicrobial properties. Also has been explored the possibility of the in vitro tissue culture. In a first approach was obtained calluses from cotyledons of germinated seeds and maintained in a MS medium. These calluses were analyzed in the production of alkaloids and were observed that erythraline and the erythtroidines are the major alkaloids (GarciaMateos, et al., 1999; San Miguel-Chávez, et al., 2003.)

Subsequently cell suspension culture were induced from calluses what showed an efficient production of alkaloids in MS medium plus sucrose. The alkaloids obtained in these tissue culture were erythraline, 8-oxo-erythraline erysodine, a-and $\beta$-erythroidine, erysotramidine, and 8-oxo-a-erythroidine, but with levels below of those of the calluses (San Miguel-Chávez, et al., 2003). Trying to increase the alkaloid production in cell suspension culture, the concentration and type of plant growth regulation has been managed, and kinetin, indol acetic acid, naphthalene acetic acid and 2,4-phenoxyacetic acid have been tested and the treatment with MS medium plus 2,4-D+ kinetin (2 $\mathrm{mg} \mathrm{l}^{-1}$ each one) gave the best results (San Miguel-Chávez, et.al., 2003). 
In another step it has been elicited the cell suspension culture with jasmonic acid and only erysodine increased its production (San Miguel-Chávez, et al., 2007).

\section{Compounds of non alkaloid composition}

Besides of the presence of alkaloids in the Erythrina plants, has been detected the presence of diverse metabolites, for example glucoproteins or lectins with the characteristic to agglutinate cells (Ortega, et al. 1990). Stojanovic \& coworkers, characterized a lectin isolated from E. velutina which is a good agglutinant agent of erytrocites A, B and $\mathrm{O}$ in human beings (Stojanovic, et al., 1994).

The saponins sigmoidin $\mathrm{C}$ and D were isolated from the steam bark of E. sigmoidea Hua and have been used in Cameroon as antimicrobial agents (Mbafor, et al., 1997). Also from this species have been recently isolated a new antibacterial triterpenoid saponin called Sigmoiside E (Kouam, et al., 2007). In E. crista-galli were isolated 3 new pterocapans: cristacarpin, erystagallin and phaseollidin with phytoalexin properties and possessing antimicrobial activity against Gram- positive bacteria (Tanaka, et al., 1997). The erystagallinA also isolated from the stem bark of E. variegata L. showed significant anti-cancer activity against breast cancer T47D cell-lines in vitro using the Sulforhodamine B(SRB) assay and anti-malarial activity against Plasmodium falciparum in vitro using the lactate dehydrogenase (LDH) assay (Tati, et al., 2011). It is interesting to note that the pterocarpene, erycristagallin isolated from root bark of E. mildbraedii (Njamen, et al., 2003) showed anti-inflammatory properties through its capacity to inhibit the arachidonic acid metabolism via the 5lipooxygenase pathway.

Fomum and coworkers (1986) found in the bark of E.sigmoidea three new phenyl flavanones: sigmoidine A, B and C with a notorious activity against, Gram- positive bacteria (Fomum, et al., 1986).

In the seeds of Erythrina also have been detected protease inhibitors, for instance Joubet \& coworkers found this kind of compounds against tripsine, which acts as activator of the plasminogen tissue (Joubet, et al. 1987). In this way, continue an intense research with diverse species of Erythrina with the aim to characterize other compounds with notorious antibiotic activity and anticancer for example Cui \& coworkers described four new chalcones 1 to 4 called abyssinones A-D isolated from E. abyssinica. They showed a moderate cytotoxic against $\mathrm{Caco} 2$ cell line of human colorectal cancer with $\mathrm{IC}_{50} 13.3,15.1$ and $11.1 \mu \mathrm{M}$ respectively( Cui, et al. 2008).

Previously in this species Yenesew \& coworkers (2004) found in the ethyl acetate extract of the bark, anti plasmodial activity against the chloroquine sensible (D6) and chloroquineresistant (W-2) strains in Plasmodium falciparum with values of $\mathrm{IC}_{30}$ of $7.9 \pm 1.1$ and 5.3 I 0.7 $\mathrm{mg} \mathrm{ml}$ respectively (Yenesew, et al. 2003, 2004).

Also several flavonoids (Chacha, et al. 2005; Chukwujekwu, et al., 2011; Doughari, 2011), isoflavonoids (Sato, et al., 2006; Kamdem Waffo, et al., 2006; Redko, et al., 2007) and pterocarpanes (Rukachaisirikul, et al., 2007a; 2007b) have been mentioned as antimicotic and antibacterial agents. For instance, an arylbenzofuran, erypoegin $\mathrm{F}$ and four isoflavonoids, erypoegins G-J were isolated from the roots of E. poeppigiana and their structure were elucidated by spectroscopic evidence (Tanaka, et al., 2003). 
Also is important to mention the study done by Tanaka \& coworkers (Tanaka, et al. 2010) in which they isolated two new compounds from the roots of E. herbaceae, erybacin $A$ and erybacin B, as a 1-hydroxy-1,3-diphenylpropan-2-one derivatives. These compounds were evaluated for their antibacterial activities against 13 strains of methicillin resistant Staphylococcus aureus (MRSA), the erybacy B showed a potent bactericidal activity against MRSA.

The stem bark of E. senegalensis studied by its hepatoprotective properties have been recently studied by the presence of prenyl isoflavonoids as novel HIV-1 protease inhibitors (Lee, et al., 2009). These authors found that the prenyl isoflavonoids had a dose-dependant inhibitory activities on HIV-1 PR with IC50 values from 0.5 to $30 \mu \mathrm{M}$ and mention that the isoflavonoid with prenyl groups at 6 and 8 positions of the ring $\mathrm{A}$ and one hydroxyl group in the $4^{\prime}$ position of $\mathrm{B}$ ring was the most potent HIV-1 PR inhibitor.

\section{Conclusions}

This review represents the work done in the last seventy five years in the knowledge of the Erythrina genus, a group of 120 species of the Leguminosae, with seventy of them in the Neotropics, 50 species are in Mexico, Central America and Caribbean where is used as ornamental (coral or lucky bean tree), shade tree, timber (construction, implements), living fences and enclosures, green manure, livestock, fodder, medicine and seeds are used for necklaces.

These features have contributed to a deep research of their chemical constituents as alkaloids, flavonoids, isoflavonoids, saponins and lectins. The review remarked the potential which each type of compounds have now days.

Alkaloids for instance with their unique structure have attracted attention for their synthesis and structural elucidation or their pharmacological potential given by the relaxant properties.

The flavonoids and isoflavonoids represent other of the potentials of the genus because in recent years the literature has described not only novel structures but also notorious biological activity mainly related with antimicrobial agents.

Their impact is large in developing countries due to a relative unvailability of medicines and the emergence of widespread drug resistance. Therefore researchers are increasingly diverting their attention to folk medicine, looking for new leads to develop better drugs against microbial infections

It is hoped that this review can stimulate the development of new strategies in the manage of these kind of compounds and possibly to find new active agents from this beautiful genus of plants.

\section{References}

Aguilar, M.I.; Giral, F. \& Espejo, O. (1981) Alkaloids from the flowers of Erythrina americana. Phytochem 20: 2061-2062.

Altamirano, F. (1888) Nuevos Apuntes para el estudio del Colorin, Erythrina coralloides. Gaceta Médica de Mexico 23: 369 
Amer, M.E.; Shamma, M. \& Freyer, A.J. (1991) The Tetracyclic Erythrina Alkaloids, J Nat Prod 54:329-363

Atsarno, AD.; Nguelefack, T.B.; Datte, J.Y. \& Kamanyi, A. (2011) Acute and subchronic oral assessment of the aqueous extract from the stem bark of Erythrina senegalensis DC(Fabaceae) in rodents, J. Ethnopharmacol. 134 (3): 697-702.

Barton, D.H.R. \& Cohen, T. (1957) Some Biogenetic Aspects of Phenol Oxidation. In Festschrift Professor Dr. Artur Stoll. Basel: Birkhäuser

Barton, D.H.R.; Boar, R.B. \& Widdowson, D.A. (1970) Phenol Oxidation and Biosynthesis Part XXI. The Biosynthesis of the Erythrina Alkaloids, J Chem Soc C 1213.

Barton, D.H.R.; Potter, C.J. \& Widdowson, D.A. (1974) Phenol Oxidation and Biosynthesis Part XXIII. On the benzyltetrahydroisoquinoline Origins of the Erytrina Alkaloids. J Chem Soc Perkin Trans 1346

Barton, D.H.R.; James, R.; Kirby, G.W.; Turner, D.W. \& Widdowson, D.A. (1968) Phenol Oxidation and Biosynthesis. Part XVIII.The Structure and Biosynthesis of Erythrina Alkaloids. J Chem Soc C 1529

Boekelheide, V. ;Weinstock, J.; Grundon, M.F.; Sauvage, G.L. \& Agnello, E.J. (1953) The structure of $\beta$-Erythoidine and its derivatives. J. Amer. Chem. Soc. 75:2550

Bourgard, F.; Gravot, A.; Milesi, S. \& Gontier, E. (2001) Production of plant secondary metabolites: a historical perspective, Plant Science 161, 839-851.

Carvalho, A.C.C.S.; Almeida, D.S.; Melo, M.G.D.; Cavalcanti, S.C.H. \& Marçal, R.M. (2009) Evidence of the mechanism of action of Erythrina velutina Wild (Fabaceae) leaves aqueous extract, J.Ethnopharmacol. 122: 374-378.

Carmack, M., MacKusick, B.C. \& Prelog, V. (1951) Erythrina-Alkaloide,2. Mitt Über das Apoerysodin und das Apo-erythralin. Helv Chim Acta 34:1601

Chacha, M.; Bojase-Moleta, G. \& Majinda, R.R.T. (2005) Antimicrobial and radical scavenging flavonoids from the stem wood of Erythrina latissima, Phytochemistry. 66 (1): 99-104.

Cheeta, S.; Tucci, S. \& File, S.E. (2001) Antagonism of the Anxiolytic Effect of Nicotine in the dorsal raphé nucleus by dihydro- $\beta$-erythroidine, Pharmacol. Biochem Behavior 70:491-496

Chukwujekwu, J.C.; Van Heerden, F.R. \& Van Staden, J. (2011) Antibacterial Activity of Flavonoids from the Stem Bark of Erythrina caffra Thumb., Phytother. Res. 25: 46-48.

Craig, L.E. (1955) Curare-like Effects In: The alkaloids, Chemistry and Physiology Vol.5Pharmacology. Manske, R.H.F. (Ed.) p. 265-290, Academic Press, New York.

Cui, L. ; Thuong,P.T.; Lee, H.S; Njamen, D.; Mbafor, J.T.; Fomum, Z T , Lee, J.; Kim Y.H. \& Oh, W.K. (2008) Four new chalcones from Erythrina abyssinica, Planta Medica, 74 (4): 422-426.

Decker, M.W.; Anderson, D.J.; Brioni, J.D.; Donelly-Roberts, D.L.; Kang, C.H.; O’Neill, A.B.: Piattoni-Kaplan, M.; Swanson, S. \& Sullivan, J.P. (1995) Erysodine, a competitive antagonist at neuronal nicotinic acetylcholine receptors, Eur J. Pharmacol 280: 79.

Dominguez, M. \& Altamirano, F. (1877) Del Colorín, Gaceta Médica de México 12:77.

Doughari, J.H. (2010) Evaluation of antimicrobial potential of stem bark extracts of Erythrina senegalensis DC , Afr. J. Microbiol. Res. 4(7): 1836-1841.

Dyke, S.F. \& Quessy S.N. (1981). Erythrina and related alkaloids, In: The Alkaloids. Vol. 18. Manske R F H (ed.),1-98 Academic Press. New York.

Fabre, N.; Claparols, C.; Richelme, S.; Angelin, M.L.; Fourasté, I. \& Moulis, C. (2000) Direct characterization of isoquinoline alkaloids in a crude plant extract by ion-pair liquid chromatography-electrospray ionization tandem mass spectrometry: example of Eschscholziacalifornica, J. Chromatogr. A. 904, 35-46 
Faria, T.D.J. , Cafèu, M.C.; Akiyoshi, G.; Ferreira, D.T.; Galao, O.F., Andrei, C.C.; Pinge Filho, P.; Paiva, M.R.C.; Barbosa, A.D.M. \& Braz-Filho, R. (2007) Alkaloids from flowers and leaves of Erythrina speciosa Andrews, Quimica Nova 30 (3): 525-527.

Fischer, L.G..O.; Leitao, R.; Etcheverry, S.R.; De Campos-Buzzi, F.; Vazquez, A.A.; Heinzen, H.A. \& Filho, C.(2007) Analgesic properties of extracts and fractions from Erythrina crista-galli (Fabaceae) leaves, Nat. Prod. Res. 21(8): 759-766.

Flausino, O. Jr.; de Avila Santos, L.; Verli, H.; Pereira, AM., da Silva Bolzani, V. \& Nunez-deSouza R.L. (2007a) Anxiolytic Effects of Erythrinan Alkaloids from Erythrina mulungu, J. Nat. Prod. 70: 48-53.

Flaustino, O.P. Jr.; Pereira, A.M., da Silva Bolzani, V \& Nunez-de-Souza R.L. (2007b) Effects of Erythrinan Alkaloids isolated from Erythrina mulungu (Papilionaceae) in Mice Submitted to Animal Model of Anxiety, Biol. Pharm. Bull. 30(2): 375-378.

Folkers, K. \& Major, R.T. (1937) Isolation of Erythroidine, an Alkaloid of Curare Action from Erythrina americana Mill. J. Am Chem Soc 59:1580

Folkers, K. \& Koniuszy, F. (1939) Erythrina alkaloids, III. Isolation and Characterization of a new alkaloid, Erythramine, J. Am Chem Soc 31:1232

Folkers, K. \& Koniuszy, F. (1940a) Erythrina Alkaloids. VII. Isolation and Characterization of the New Alkaloids, Erythraline and Erythratine, J. Am Chem Soc 62:436

Folkers, K. \& Unna K. (1938) Erythrina alkaloids, II. A review, and New Data on the Alkaloids of Species of the Genus Erythrina. J. Am Pharm Assoc 27:693

Folkers, K. \& Unna, K. (1939) Erythrina alkaloids V. Comparative Curare-like Potencies of Species of the Genus Erythrina. J. Pharm Assoc 28:1019.

Folkers, K.\& Koniuszy, F. (1940b) Erythrina alkaloids VIII. Studies on the Constitution of Erythramine and Erythraline, J Am Chem Soc 62:1673

Folkers, K.\& Koniuszy, F. (1940c) Erythrina Alkaloids. IX. Isolation and Characterization of Erysodine, Erysopine, Erysocine and Erysovine, J Am Chem Soc 62: 1677

Fomum, Z.T.; Ayafor, J.F.; Mbafor, J.T. \& Mbi, Ch.M. (1986) Erythrina studies. Part 2. Structures of three novel prenylated antibacterial flavanones, sigmoidins A-C, from Erythrina sigmoidea Hua, J Chem Soc Perkin Trans I: 33-37.

García-Mateos, R.; Garín-Aguilar, M.E.; Soto-Hernández, M \&. Martínez-Vazquez, M. (2000) Effect of $\beta$-Erythroidine and $\beta$-Dihydroerythroidine from Erythrina americana on rats Aggressive Behavior, Pharm Pharmacol Lett 10:34

García-Mateos, R.; Soto-Hernández, M.; Martínez-Vázquez, M. \& Villegas- Monter A. (1999) Isolation of alkaloids of Erythrina from tissue culture, Phytochemical analysis. 10: 12-16.

Garín-Aguilar, M.E.; Ramírez- Luna, J.E.; Soto-Hernández, M.; Valencia del Toro, G. \& Martínez- Vazquez, M. (2000) Effect of crude Extracts of Erythrina americana Mill. on aggressive behaviour in Rats, J. Ethnopharmacol 69:189

Garín-Aguilar, M.E.; Valencia del Toro, G., Soto-Hernández, M. \& Kite, G. (2005) Highperformance liquid chromatography-mass spectrometric analysis of alkaloids extracted from seeds of Erythrina herbacea, Phytochemical Analysis 16: 302-306

Ghosal, S.; Dutta, S. \& Bhattacharya, S.K. (1972) Erythrina - Chemical and Pharmacological Evaluation II: Alkaloids of Erythrina variegata 1, J. Pharm Sci 61:1274

Greshoff, M (1890) Mitteilungen aus dem chemisch-pharmakologisehen Laboratorium de Botanischen Gartens zu Buitenzorg (Java), ChemBer 23: 3537. 
Hargreaves, R.T., Johnson, R.D.; Millington, D.S.; Mondal, M.H.; Beavers, W.; Becker, L.; Young, C., \& Rinehart, K.L. Jr (1974) Alkaloids of American Species of Erythrina, Lloydia 37:569-580

Hegnauer, R. (1963). Chemotaxonomy, past and present. Lloydia 28: 267-278.

Iturriaga-Vasquez, P.; Carbone, A.L.; García-Beltrán, O.; Livingstone, P.D; Biggin, P.C.; Cassels, B.K.; Wonnacott, S.; Zapata-Torres, G. \& Bemudez, I. (2010) Molecular Determinants for Competitive Inhibition of a $4 \beta 2$ Nicotinic Acetylcholine Receptors, Molec Pharmacol. 78(3): 366-375.

Jackson, A.H.; Ludgate, P.; Mavraganis, V. \& Redha, F.M. (1982). Studies of Erythrina alkaloids, part V.GC/MS investigation of alkaloids in the seeds of E. subumbrans, E. lanata, E. rubinervia, E. acanthocarpa, E. variegate and E. melanacantha, Allertonia 3: 47-51

Joubet, J.J.; Merrifiel, E.H. \& Dowdle, E.B.D. (1987). The reactives sites of proteinase inhibitors from Erythrina seeds, International Journal of Biochemistry 19: 601-606.

Juma, B. \& Majinda, R.R.T. (2004) Erythrinaline alkaloids from the flowers and pods of Erythrina lysistemon and their DPPH radical scanvenging properties, Phytochem. 65: 1397-1404.

Kamdem Waffo, A.F.; Coombes, P.H.; Mulholland, D.A.; Nkengfack, A.E. \& Fomum Z.T. ( 2006) Flavones and isoflavones from the west African Fabaceae Erythrina vogelii, Phytochem 67: 459-463

Kawasaki, T.; Onoda, N.; Watanabe, H. \& Kitara, T. (2001) Total Synthesis of ( \pm ) Cocculolidine. Tetrahedron Lett 42: 8003

Kenner, G.W., Khorana, H.G. \& Prelog, V. (1951) Erythrina-Alkaloide, 3. Mitt. Über den Hoffman'schenAbbau des Tetrahydro-erysotrins und des Tetrahydro-erythralins. Helv Chim Acta 34:1969

Kouam, J. ; Noundou, X.Siewe Noundou, X.; Kouitcheu Mebeku, L.B.; Meli Lannang, A.; Choudhary, M.I. \& Fomum, Z.T.(2007) Sigmoiside E: A New Antibacterial Triterpenoid Saponin from Erythrina sigmoidea HUA, Bull. Chem. Soc Ethiop 21(3): 373-378.

Kumar, A; Lingadurai, S.; Shirivastava, T.P.; Bhattacharya, S. \& Haddar, P.K. (2011) Hypoglycemic activity of Erythrina variegata leaf in streptozotocin-induced diabetic rats, Pharm. Biol. 49(6): 577-582.

Lee, J.S.; Oh, W.K.; Ahn, J.S.; Kim, Y.H.;Mbafor, J.T.; Wandji, J. \& Fomum, Z.T. (2009) Prenylisoflavonoids from Erythrina senegalensis as Novel HIV-1 Protease Inhibitors, Planta Med. 75:268-270.

Lehman, A.J. (1936) Curare-Actions of Erythrina americana, Proc Soc Exp Biol Med 33: 501

Lehman, A.J. (1937) Action of Erythrina americana, a possible Curare Substitute, J Pharmacol Exp Ther 60: 69

Lozoya, X. \& Lozoya, M. (1982) Flora Medicinal de México. In: Plantas Indígenas del Seguro Social, México, D.F. p 174

Maier, U.H. \& Zenk, M.H. (1997), (S)-Norrreticuline is the precursor for the biosynthesis of Erythrina alkaloids, Chem Commun.2313-2314.

Maier, U.H.; Rödl, W.; Deus-Neumann B. \& Zenk, M.H. (1999) Biosynthesis of Erythrina Alkaloids in Erythrina crista-galli . Phytochemistry 52: 373

Mantle, P.G. (1995). Direct analysis of aromatic diene Erythrina alkaloids by capillary GC-MS Phytochemistry 38: 135-1316

Mbafor, T. J.; Ndom, J.C. \& Fomum, T.Z..( 1997). Triterpenoids saponins from E. sigmoidea, Phytochemistry 44 (6): 1151-1155. 
Mondon, A.; Hansen, K.F.; Boehme, K.; Faro, H.P.; Nestler, H.J.; Vilhuber, H.G. \& Böttcher, K. (1970) SynthetischeArbeiten in der Reidhe der aromatischen Erythrina-Alkaloide, XI; Anwendungen der Glyoxylester-Synthese, Chem Ber 103:615

Murphy, A.C. (2011) Metabolic engineering is key to sustainable chemical industry, Nat Prod Rep 28, 1406-1425.

Nagaraja, T.S., Mahmood, R.; Krishna, V. \& Maruthi,E.T. (2011) Evaluation of antimicrobial activity of Erythrina mysorensis Gamb. Int J. Drug Devel. \& Res., 3 (2):198-202.

Njamen,D.; Talla, E.; Mbafor, J.T.; Fomum, Z.T.; Kamanyi, A.; Mbanya, J.C.; Cerda-Nicolas, M.; Giner, R.M.; Recio, M.C. \& Ríos, J.L.(2003) Anti-inflammatory activity of erycristagallin, a pterocarpene from Erythrina mildbraedii, Eur. J. Pharmacol. 468:67-74.

Ortega, M.; Sánchez, C.; Chacón, E.; Rendón, L.J.; Estrada, R.; Masso, F. Montaño, F.L. \& Zenteno,E. (1990) Purification and characterization of a lectin from Erythrina americana by affinity chromatography, Plant Science 72: 133-140.

Ozawa, M.; Kawamata, S.; Etoh, T.; Hayashi, M.; Komiyama, K.; Kishida, A.; Kuroda, Ch. \& Ohsaki, A. (2010) Structures of new Erythrinan alkaloids and Nitric Oxide Production Inhibitors from Erythrina crista-galli, Chem Pharm. Bull. 58(8): 1119-1122

Ozawa, M.; Kishida, A. \& Ohsaki, A. (2011) Erythrinan Alkaloids from Seeds of Erythrina velutina, Chem Pharm. Bull. 59(5):564-567.

Pick, E.P. \& Unna, K. (1945) The effect of Curare and Curare -like substances on the Central Nervous System, J. Pharmacol. Exp Therap 83:59

Ramírez, E. \& Rivero, M.D. (1935) Pharmacodynamic Action of Erythrina americana Mill [family leguminosae]. Anales Inst. Biol. (Mex) 6:301 .

Redko, F. ; Clavin, M.L.; Weber, D.; Ranea, F.; Anke, T. \& Martino, V. (2007) Antimicrobial isoflavonoids from Erythrina crista galli infected with Phomopsis sp., Z. Naturforschung. C, 62 (3-4):164-168.

Reiman, E. \& Ettmayr, C. (2004) An Improved Stereocontrolled Route to cis-Erythrinanes by Combined Intramolecular Strecker and Bruylants Reaction. Monatsh Chem 135:1143

Rey, P. (1883) Note sur les proprietés thérapeutiques de l’Erythrina corallodendron Le Journal de Terapeutique 10: 843.

Rukachaisirikul,T.; Innok, P.; Aroonrerk, N.; Boonamnuaylap, W.; Limrangsun, S.; Boonyon, Ch.; Woonjina, U.;Suksamrarn, A. (2007) Antibacterial pterocarpans from Erythrina subumbrans, J Ethnopharmacol. 110 (1): 171-175.

Rukachaisirikul, T.; Saekee, A.; Tharibun, Ch.; Watkoulham, S. \& Suksamrarn, A.(2007b) Biological Activities of the Chemical Constituents of Erythrina stricta and Erythrina subumbrans, Arch.Pharm Res 30(11): 1398-1403

Rukachaisirikul, T.; Innok, P. \& Suksamrarn, A. (2008) Erythrina Alkaloids and a Pterocarpan from the Bark of Erythrina subumbrans, J. Nat Prod. 71: 156-158.

San Miguel-Chávez, R.; Soto-Hernández, M.; Ramos-Valdivia A.C. \& Kite, G. (2007) Alkaloid production in elicited cell suspension cultures of Erythrina americana Miller, Phytochem Rev. 6: 167-173.

San Miguel-Chávez, R.; Soto-Hernández, M.; Ramos-Valdivia, A.C.; Kite, G.; MartínezVázquez, M.; García-Mateos, R.\& Terrazas, T. (2003) Production of alkaloids by in vitro culture of Erythrina americana Miller, Biotechnol Lett. 25(13): 1055-1059.

San Miguel-Chávez, R.; Soto-Hernández, M.; Terrazas, T. \& Kite,.G. (2006) Morphology and alkaloidal profile of the seedlings of Erythrina americana Mill, and E. coralloides A.D, Feddes Repertorium. 117 (3-4): 232-239. 
Sato, M.; Tanaka, H.; Tani, N.; Nagayama, M. \& Yamaguchi, R.( 2006). Different antibacterial actions of isoflavones isolated from Erythrina poeppigiana against methicillinresistant Staphylococcus aureus, Letters Applied Microbiology. 43 (3): 243-248.

Schoffelmer, A.N.M.; De Vries, T.J.; Wardeh, G.; van de Ven, H.W.M. \& Venderschuren I. J.M.J. (2002) Psychostimulant-Induced Behavioral Sensitization Depends on Nicotinic Receptor Activation, J. Neurosci 22:3269

Silva, D.S.B.S.; Garcia, A.CF.S.; Mata, S.S.; de Oliveira, B.; Estevam, Ch.S.; Scher, R. \& Pantaleao, S.M. (2011) Genotoxicity and citotoxicity of Erythrina velutina Willd., Fabaceae, on the root meristem cells of Allium cepa, Braz. J. Pharmacog. 21(1):92-97.

Sonia, J.; Latha, P.G; Gowsalya, P.; Anuja, G.I.; Suja, S.R.; Shine, V.J.; Shymal, S.; Shikha, P.; Krishnakumar, N.M.; Sreejith, G.; Sini, S.\& Sekharan, S. (2011) Antidiarrhoeal effects of ethanolic leaf extract of Erythrina indica L. in experimental animals, Med. Plants 3(1)

Soto-Hernández, M. \& Jackson, A.H. (1994) Erythrina alkaloids: isolation and characterization of alkaloids from seven Erythrina species, Planta Med 60: 175-177

Stojanovic, D.; Fernández, M.; Casale, I.; Trujillo, D. \& Castes, M.. (1994). Characterization and mitogenicity of a lectin from Erythrina velutina seeds, Phytochem 37: 1069-1074.

Tanaka, H.; Tanaka, T. \& Etoh, H.( 1997). Three pterocarpans from E. crista-galli, Phytochem 45 (4): 835-838.

Tanaka, H.; Etoh, H.; Shimizu, H.; Oh-Uchi, T.; Terada, Y. \& Tateishi, Y.( 2001) Erythrinan alkaloids and isoflavonoids from Erythrina poeppigiana, Planta Med 67:871-873.

Tanaka, H.; Oh-Uchi, T.; Etoh, H.; Sako, M.; Sato, M.; Fukai, T. \& Tateishi, Y. (2003) An arylbenzofuran and four isoflavonoids from the roots of Erythrina poeppigiana, Phytochem 63: 597-602.

Tanaka, H.; Hattori, H.; Tanaka, T.; Sakai, E.; Tanaka, N.; Kulkarni, a. \& Etoh H.(2008) A new Erythrina alkaloid from Erythrina herbacea, J Nat Med 62:228-231.

Tanaka, H.; Sudo, M.; Kawamura, T.; Sato, M.; Yamaguchi, R.; Fukai, T.; Sakai, E. \& Tanaka N. ( 2010) Antibacterial Constituents from the Roots of Erythrina herbacea against Methicillin-resistant Staphylococcus aureus, Planta Med 76: 916-919.

Tati, H.; Nurlelasari ; Dikdik, K.; Unang, S. and Zalinar, U. (2011) In vitro anticancer and antimalarial Erystagallin-A from Erythrina variegata (L) stem bark, Med Plant 3(1)

Tsuda, Y. \& Sano, T. (1996) Erythrina and Related Alkaloids. In: The Alkaloids, vol. 48, G.A Cordell (Ed.), 249-338 Academic Press, Inc., New York.

Verpoorte, R. \& Niesse, W.M.A. (1994). Liquid chromatography coupled with mass spectrometry in the analysis of alkaloids. Phytochem. Anal. 5. 217-232

Wanjala, C.C.W. \& Majinda, R.T. (2000) Two Novel Glucodienoid Alkaloids from Erythrina latissima Seeds, J Nat Prod 63: 871-873.

Wanjala, C. C.W.; Juma, B.F.; Bojase, G.; Gashe, B.A. \& Majinda, R.R.T. (2002) Erythrinaline alkaloids and Antimicrobial Flavonoids from Erythrina latissima, Planta Med 68:640-642

Wanjala, C.W., Akeng'a, T.; Obiero, G.O. \& Lutta, K.P. (2009) Antifeedant Activities of the Erythrinaline Alkaloids from Erythrina latissima against Spodoptera littoralis (Lepidoptera noctuidae), Rec. Nat. Prod. 3(2):96-103

Yenesew, A.; Derese, S.; Irungu, B.; Midiwo, J.O.; Waters, N.C., Liyala, P.; Akala, H.;Heydenreich, M. \& Peter, M.G. (2003) Flavonoids and Isoflavonoids with Antiplasmodial Activities from the Root Bark of Erythrina abyssinica, Planta Med 69:658-661

Yenesew, A.; Induli, M.; Derese, S.; Midiwo, J. O.; Heydenreich, M.; Peter, M.G.; Akala, H.; Wangui, J.; Liyala, P.\& Waters, N.C. (2004) Anti-plasmodial flavonoids from the stem bark of Erythrina abyssinica, Phytochem 65 (22): 3029-3032 


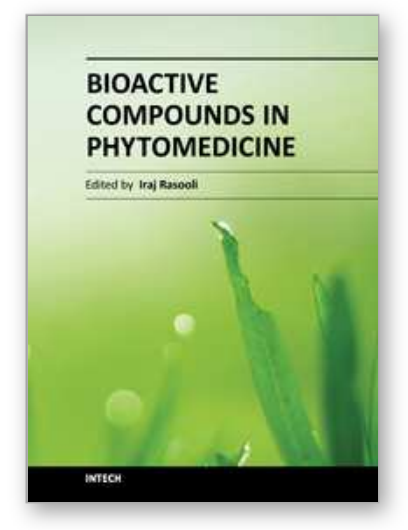

\author{
Bioactive Compounds in Phytomedicine \\ Edited by Prof. Iraj Rasooli
}

ISBN 978-953-307-805-2

Hard cover, 218 pages

Publisher InTech

Published online 18, January, 2012

Published in print edition January, 2012

There are significant concerns regarding the potential side effects from the chronic use of conventional drugs such as corticosteroids, especially in children. Herbal therapy is less expensive, more readily available, and increasingly becoming common practice all over the world. Such practices have both their benefits and risks. However, herbal self-therapy might have serious health consequences due to incorrect self-diagnosis, inappropriate choice of herbal remedy or adulterated herbal product. In addition, absence of clinical trials and other traditional safety mechanisms before medicines are introduced to the wider market results in questionable safe dosage ranges which may produce adverse and unexpected outcomes. Therefore, the use of herbal remedies requires sufficient knowledge about the efficacy, safety and proper use of such products. Hence, it is necessary to have baseline data regarding the use of herbal remedies and to educate future health professionals about various aspects of herbal remedies.

\title{
How to reference
}

In order to correctly reference this scholarly work, feel free to copy and paste the following:

R. Marcos Soto-Hernández, Rosario Garcia-Mateos, Rubén San Miguel-Chávez, Geoffrey Kite, Mariano Martinez-Vázquez and Ana C. Ramos-Valdivia (2012). Erythrina, a Potential Source of Chemicals from the Neotropics, Bioactive Compounds in Phytomedicine, Prof. Iraj Rasooli (Ed.), ISBN: 978-953-307-805-2, InTech, Available from: http://www.intechopen.com/books/bioactive-compounds-in-phytomedicine/erythrina-apotential-source-of-chemicals-from-the-neotropics

\section{INTECH}

open science | open minds

\section{InTech Europe}

University Campus STeP Ri

Slavka Krautzeka 83/A

51000 Rijeka, Croatia

Phone: +385 (51) 770447

Fax: +385 (51) 686166

www.intechopen.com

\section{InTech China}

Unit 405, Office Block, Hotel Equatorial Shanghai

No.65, Yan An Road (West), Shanghai, 200040, China

中国上海市延安西路65号上海国际贵都大饭店办公楼405单元

Phone: +86-21-62489820

Fax: $+86-21-62489821$ 
(C) 2012 The Author(s). Licensee IntechOpen. This is an open access article distributed under the terms of the Creative Commons Attribution 3.0 License, which permits unrestricted use, distribution, and reproduction in any medium, provided the original work is properly cited. 